\title{
UNIVERSITYOF
}

FORWARD

THINKING

WESTMINSTER ${ }^{\text {网 }}$

WestminsterResearch

http://www.westminster.ac.uk/westminsterresearch

Understanding the Impact of E-commerce on Last-Mile Light Goods Vehicle Activity in Urban Areas: The Case of London

Allen, J., Piecyk, M., Piotrowska, M., McLeod, F., Cherrett, T.,

Ghali, K., Nguyen, T., Bektas, T., Bates, O., Friday, A., Wise, S. and Austwick, M.

NOTICE: this is the authors' version of a work that was accepted for publication in Transportation Research Part D: Transport and Environment. Changes resulting from the publishing process, such as peer review, editing, corrections, structural formatting, and other quality control mechanisms may not be reflected in this document. Changes may have been made to this work since it was submitted for publication. A definitive version was subsequently published in Transportation Research Part D: Transport and Environment, DOI:10.1016/j.trd.2017.07.020 in 2017.

The final definitive version in Transportation Research Part D: Transport and Environment is available online at:

https://dx.doi.org/10.1016/j.trd.2017.07.020

(C) 2017. This manuscript version is made available under the CC-BY-NC-ND 4.0 license http://creativecommons.org/licenses/by-nc-nd/4.0/

The WestminsterResearch online digital archive at the University of Westminster aims to make the research output of the University available to a wider audience. Copyright and Moral Rights remain with the authors and/or copyright owners.

Whilst further distribution of specific materials from within this archive is forbidden, you may freely distribute the URL of WestminsterResearch: ((http://westminsterresearch.wmin.ac.uk/)). 
In case of abuse or copyright appearing without permission e-mail repository@westminster.ac.uk 


\title{
Desirable Transport Futures Special Edition
}

\section{Understanding the Impact of E-commerce on Last-Mile Light Goods Vehicle Activity in Urban Areas: The Case of London}

\author{
Bates, O. ${ }^{4}$, Friday, A. ${ }^{4}$, Wise, S. ${ }^{5}$, and Austwick, M. ${ }^{5}$ \\ ${ }^{1}$ Faculty of Architecture and the Built Environment, University of Westminster, UK. \\ ${ }^{2}$ Faculty of Engineering and the Environment, University of Southampton, UK. \\ ${ }^{3}$ Southampton Business School, University of Southampton, UK. \\ ${ }^{4}$ School of Computing and Communications, Lancaster University, UK. \\ ${ }^{5}$ Faculty of the Built Environment, University College London, UK.
}

Allen, J. ${ }^{1}$, Piecyk, M.1, Piotrowska. M. ${ }^{1}$, McLeod, F. ${ }^{2}$, Cherrett, T. ${ }^{2}$, Ghali, K. ${ }^{2}$, Nguyen, T. ${ }^{3}$, Bektas, T. $^{3}$,

\begin{abstract}
Growth in e-commerce has led to increasing use of light goods vehicles for parcel deliveries in urban areas. This paper provides an insight into the reasons behind this growth and the resulting effort required to meet the exacting delivery services offered by e-retailers which often lead to poor vehicle utilisation in the last-mile operation, as well as the duplication of delivery services in urban centres as competitors vie for business. A case study investigating current parcel delivery operations in central London identified the scale of the challenge facing the last-mile parcel delivery driver, highlighting the importance of walking which can account for $62 \%$ of the total vehicle round time and $40 \%$ of the total round distance in the operations studied. The characteristics of these operations are in direct conflict with the urban infrastructure which is being increasingly redesigned in favour of walking, cycling and public transport, reducing the kerbside accessibility for last-mile operations. The paper highlights other pressures on last-mile operators associated with managing seasonal peaks in demand; reduced lead times between customers placing orders and deliveries being made; meeting delivery time windows; firsttime delivery failure rates and the need to manage high levels of product returns. It concludes by describing a range of initiatives that retailers and parcel carriers, sometimes in conjunction with city authorities, can implement to reduce the costs associated with last-mile delivery, without negatively impacting on customer service levels.
\end{abstract}

Keywords: light goods vehicles; urban freight; last-mile delivery; e-commerce; parcels. 


\section{Introduction}

Light goods vehicles (LGVs - up to and including 3.5 tonnes gross weight) have seen the greatest growth across London and the UK since the late 1990s whilst heavy goods vehicles (HGV - over 3.5 tonnes gross weight) and car traffic have remained relatively constant across the country, and have fallen in London (Department for Transport, 2016a; Transport for London, 2016). LGVs are used for many different purposes including goods transport, servicing activities and commuting with the former making up a significant component of total LGV activity in urban areas (Allen et al., 2012a). As business-to-business and business-to-consumer ecommerce has grown, (business-to-consumer ecommerce accounted for approximately $14 \%$ of total retail sales in the UK in 2016, and is expected to account for just over $20 \%$ of all retail sales by 2021, (Mintel, 2016a; Office for National Statistics, 2016)), the last-mile movement of parcels in our urban centres is increasing. The parcel distribution sector is highly competitive with many independent players operating with poor vehicle utilisation for low profit margins in a 'customer-focussed' delivery culture. This results in considerable duplication of effort as 'everyonedelivers-everywhere' (Browne et al., 2014), and the collective impacts of such insular behaviours on urban street performance are not well understood.

We make three contributions in this paper; firstly we provide an overview of road traffic trends in London and Britain, focussing on the growth in LGV use. We then consider the under-researched area of LGV activity including goods transport, service functions and specifically, parcel collection and delivery. Current last-mile delivery operations for packages and parcels (non-food) are examined along with the important operational factors involved, impacting on the profitability of UK online shopping retailers and parcel carriers. The results of a case study investigating current parcel delivery activity in a specific geographical location in central London are presented to illustrate the nature of these operations and the challenges they present. Finally, we identify a series of initiatives that can be used by retailers, logistics providers, local authorities and the public to improve the efficiency of business-to-consumer (B2C) and business-to-business (B2B) parcel deliveries in urban areas.

\section{The importance of light goods vehicle operations in Britain and London}

In 2015, 3.6 million LGVs were licensed in Britain, compared with 483,000 HGVs, and since 2005, the number of LGVs has increased by $23 \%$ relative to HGVs, which have fallen by $5 \%$. Over the period from 1995-2015, the number of LGVs and HGVs licensed in Britain increased by $70 \%$ and $15 \%$ respectively (Department for Transport, 2016b).

\subsection{Light goods vehicle journey purposes}

Unlike HGVs (which are almost entirely used for goods movement), LGVs are used for a wider range of purposes, including the provision of services, the transportation of goods and commuting (as many LGVs are taken home by workers overnight). Figure 1 illustrates the LGV sector in terms of the distinction between fleet LGVs (i.e. those operated by companies with sizeable fleets) and those operated by self-employed individuals and small businesses. It is also important to note that the van owner and van user can differ, and that vehicles may be sold to a company considered by the vehicle manufacturer to be a fleet buyer (for example the rental and leasing companies) although these vehicles may subsequently be rented or leased to another company, small business or individual. 


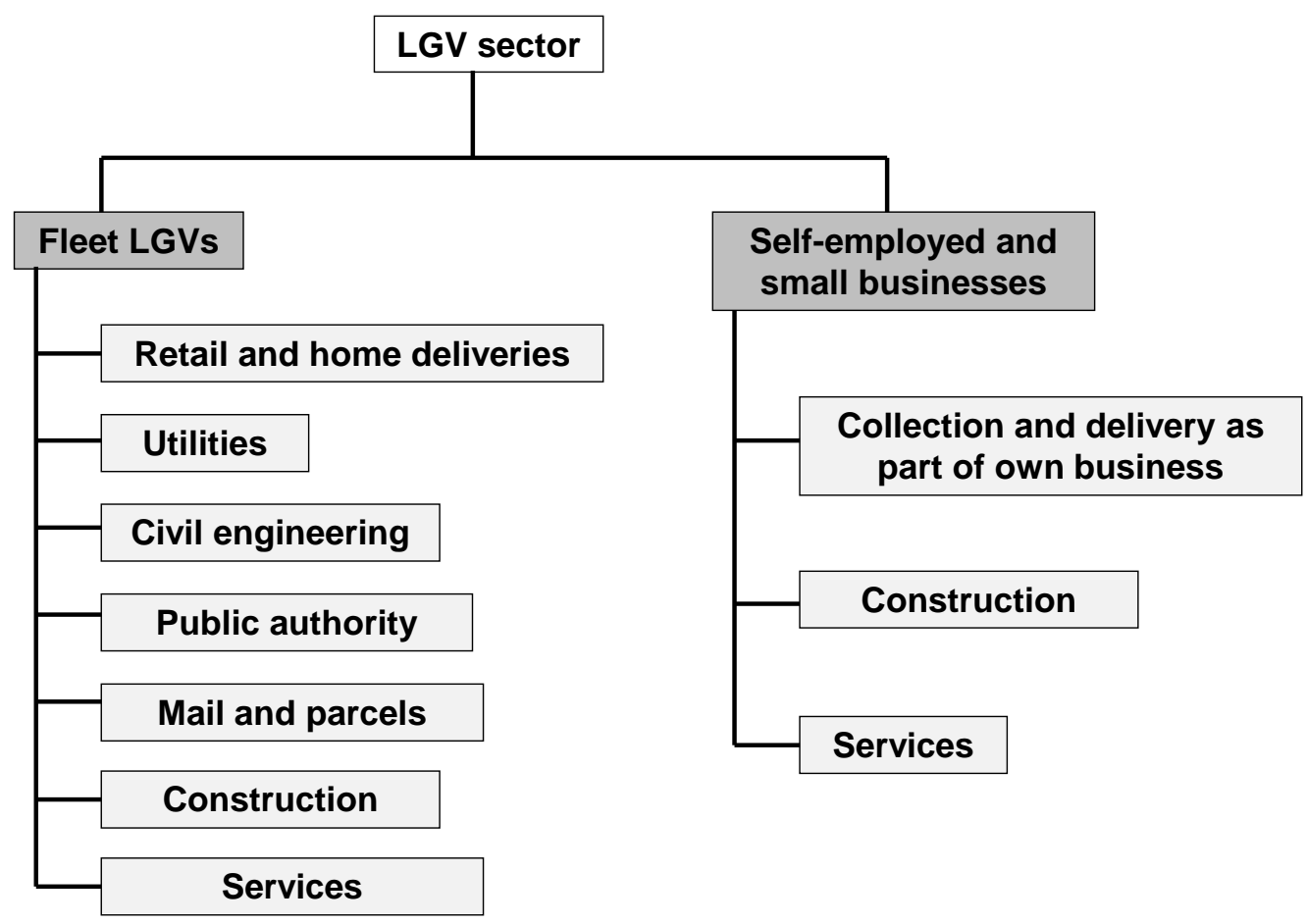

Source: adapted from CfIT (2010).

Little work has been undertaken looking into the purpose of van activity with the most reliable resource being the Department for Transport (DfT) (Department for Transport, 2004; 2007; 2009). Considering ownership and distance travelled, in the case of company-owned vans, goods collection and delivery, servicing, and commuting journeys each accounted for a similar proportion of vehicle kilometres $(34 \%, 30 \%$ and $32 \%$ respectively) with personal trips only accounting for $4 \%$ of vehicle kilometres (Department for Transport, 2007). By comparison, for privately-owned vans, commuting accounted for the greatest proportion of vehicle kilometres $(45 \%)$, followed by goods collection and delivery (23\%). Servicing journeys accounted for $15 \%$ of vehicle kilometres, while personal trips accounted for $17 \%$ (far greater than for company-owned vans), Department for Transport, (2004). When the data for company-owned and privately-owned vans is combined, the most important journey purposes in terms of total vehicle kilometres travelled were in order of importance: commuting, goods collection and delivery, and servicing, accounting for $36 \%, 30 \%$ and $25 \%$ respectively, Table 1.

Table 1: LGV vehicle kilometres accounted for by journey purpose and vehicle Ownership in Britain, 2002/3-2005

\begin{tabular}{lccc}
\hline Journey purpose & $\begin{array}{c}\text { Company- } \\
\text { owned } \\
\text { LGVs }\end{array}$ & $\begin{array}{c}\text { Privately- } \\
\text { owned } \\
\text { LGVs }\end{array}$ & All LGVs \\
\hline Servicing activity & $30 \%$ & $15 \%$ & $25 \%$ \\
Commuting & $32 \%$ & $45 \%$ & $36 \%$ \\
Goods collection and delivery & $34 \%$ & $23 \%$ & $30 \%$ \\
Personal (shopping and other) & $4 \%$ & $17 \%$ & $8 \%$ \\
Total & $\mathbf{1 0 0 \%}$ & $\mathbf{1 0 0 \%}$ & $\mathbf{1 0 0 \%}$ \\
\hline
\end{tabular}

Notes:

Company-owned LGV data is the average for 2003-2005. Privately-owned LGV data is for October 2002-September 2003. Source: calculated from data provided in Department for Transport, (2004) and Department for Transport, (2007). 
Little research has been carried out to explain the major increase in LGV traffic across Britain and London over the last twenty years but evidence has suggested that this could have resulted from (CfIT, 2010):

i) Economic growth and rising employment,

ii) Population growth and the increase in the number of households (as average household size falls),

iii) The relative lack of regulations governing LGV use compared with HGVs (leading to vehicle substitution),

iv) The rise in online shopping, last-mile delivery and the subsequent demand for express and parcels services (from businesses and residential customers),

v) The growth in more frequent, smaller volume replenishment for businesses (including retail, commercial, and construction),

vi) Expansion in the various service economy sub-sectors that involve vehicle use and the outsourcing of service functions (i.e. the use of external suppliers rather than using in-house, on-site employed service personnel),

vii) The development and use of technical and communications equipment (with its inherent maintenance and repair requirements).

\subsection{The impact of LGV activity in urban areas}

Up until relatively recently, there had been a continuously upward trend in total motorised road transport levels in Britain, and in its capital city, London (Roads Task Force, 2013a). Motorised road traffic continued to grow until 2007 after which there were three years of small declines, and then relative stability, before it began to grow again by $2.6 \%$ in 2014, and then $1.6 \%$ in 2015 . By this point, motorized road traffic levels were $0.8 \%$ above the 2007 level (Department for Transport, 2016c). In London, the level peaked in 1999, and has continued to decline ever since with the volume of motorised traffic in 2015 being 11\% less than in 1999 (Department for Transport, 2016a). This has been largely due to changes in the levels of car activity, given the relative importance of car traffic as a proportion of total motorised road traffic. By contrast, the situation has varied among HGVs and LGVs with the former remaining relatively stable across Britain and London, while the latter has continued to increase strongly following a temporary reduction at the time of the global and national economic crisis (Figures 2 and 3 ). LGV vehicle kilometres accounted for $74 \%$ and $80 \%$ of total goods vehicle activity across Britain and in London respectively in 2015 (calculated from data in Department for Transport, 2016a, Department for Transport, 2016a; and Transport for London, 2016) and have grown more than 11-fold since 1950s (Figure 4). They also comprised $15 \%$ and $14 \%$ of total vehicle kilometres travelled on roads in Britain and London respectively in 2015, compared with $10 \%$ in 1993. Despite this, car traffic in London was approximately five times greater than LGV traffic and 22 times greater than HGV traffic in 2015 (ibid).

Figure 2 shows the relative change in national traffic levels by car, LGV and HGV in Britain since 1993. This indicates that from the mid- to late-1990s until the onset of the recession in 2007/8, LGV traffic grew far more strongly than car and HGV traffic. This pattern has continued again since 2012. Figure 3 shows the relative change in traffic levels on London's roads between 1993 and 2015. This shows that LGV traffic rose strongly over the period 1993 to 2007, while car and HGV traffic levels fell after 1999 and 2000 respectively. Car and HGV traffic levels have stabilised since 2012, whereas LGV traffic has begun to rise strongly again. 
Figure 2: Vehicle kilometres travelled in Britain 1993-2015 (index $1993=100$ )

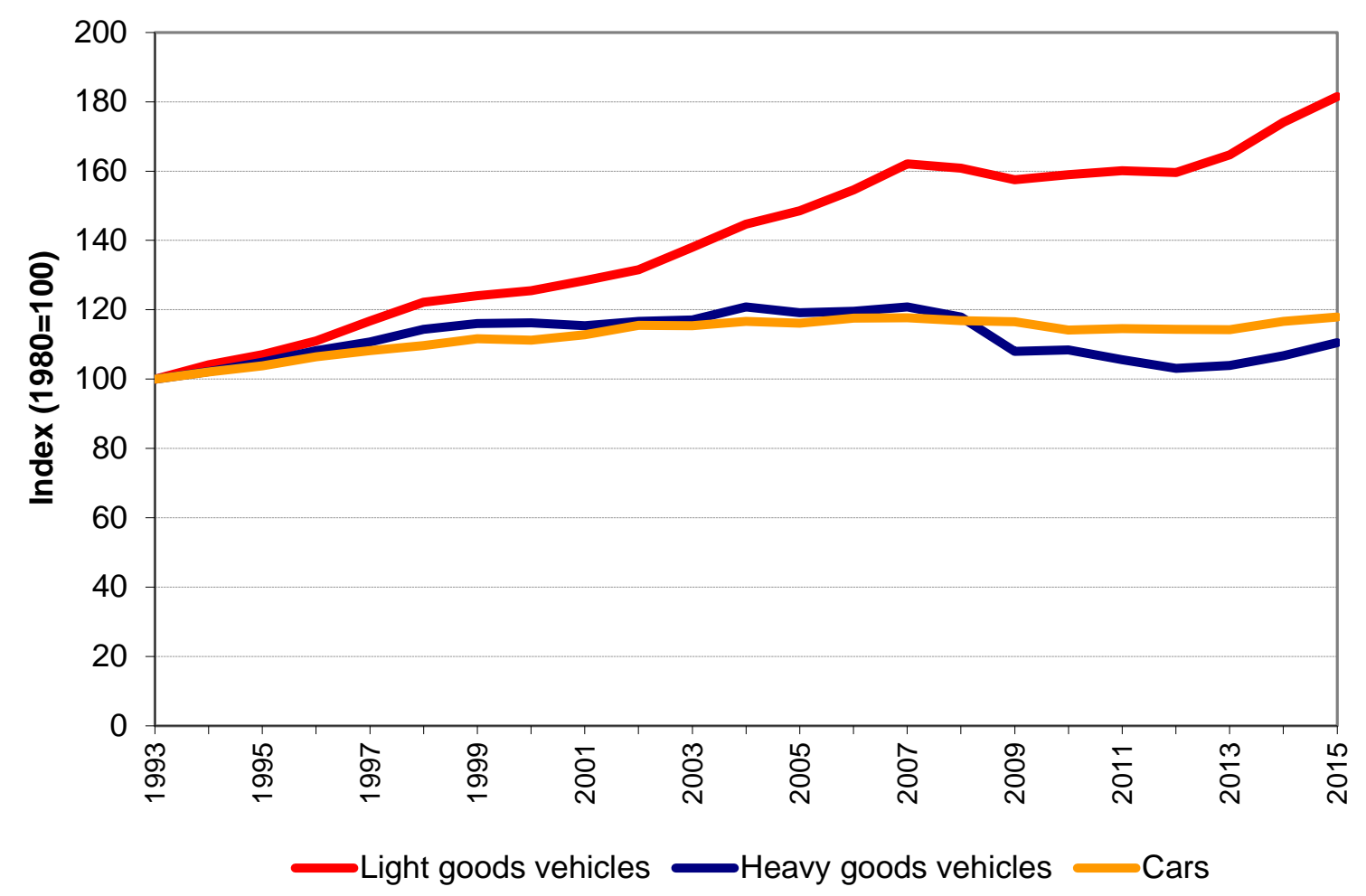

Source: Calculated from data in Department for Transport, 2016c.

Figure 3: Vehicle kilometres travelled in London 1993-2015 (index 1993 = 100)

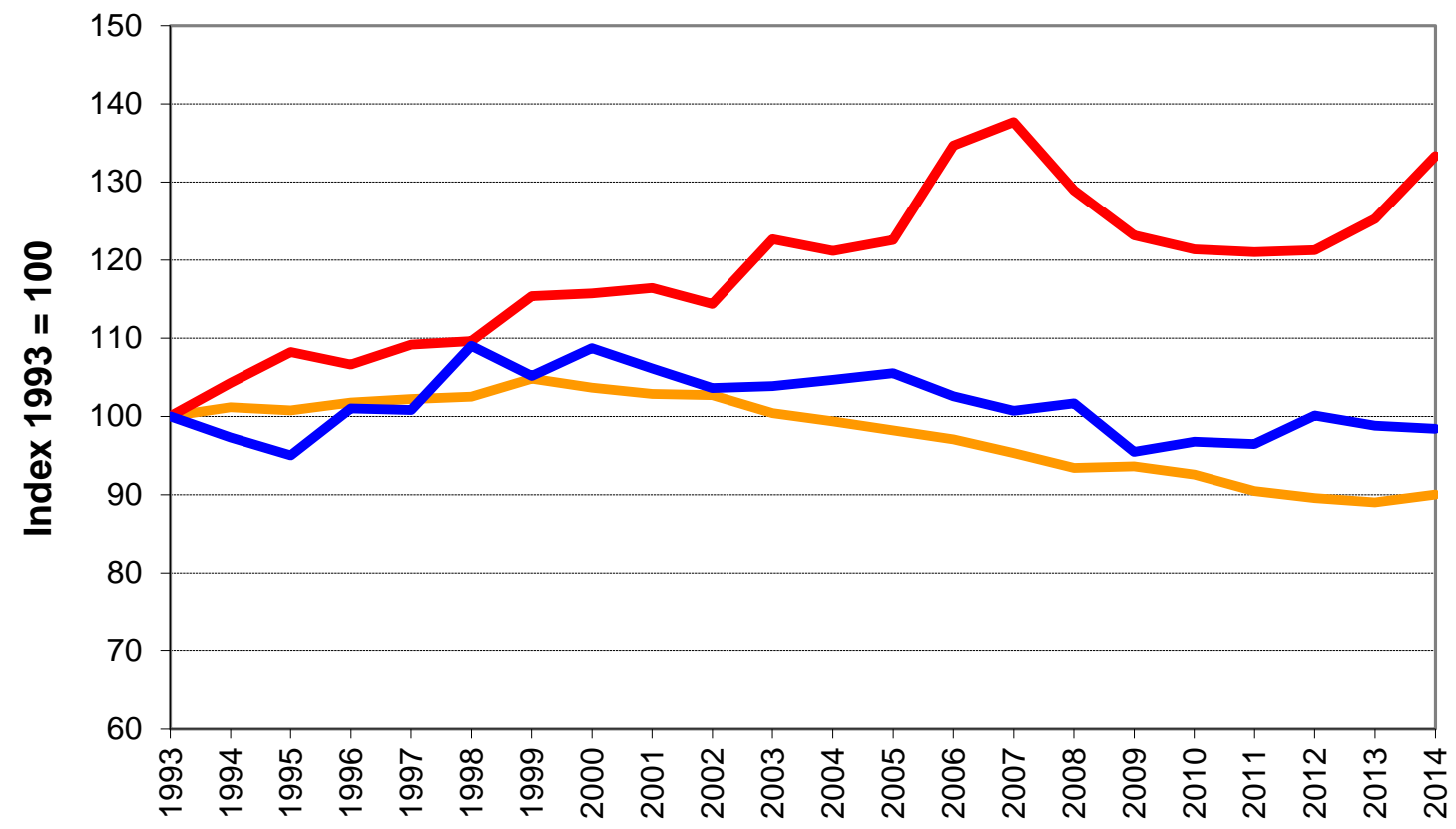

Cars and taxis $\quad$ Light goods vehicles $\quad$ Heavy goods vehicles

Source: Calculated from data in Department for Transport, 2016c; Transport for London, 2016. 


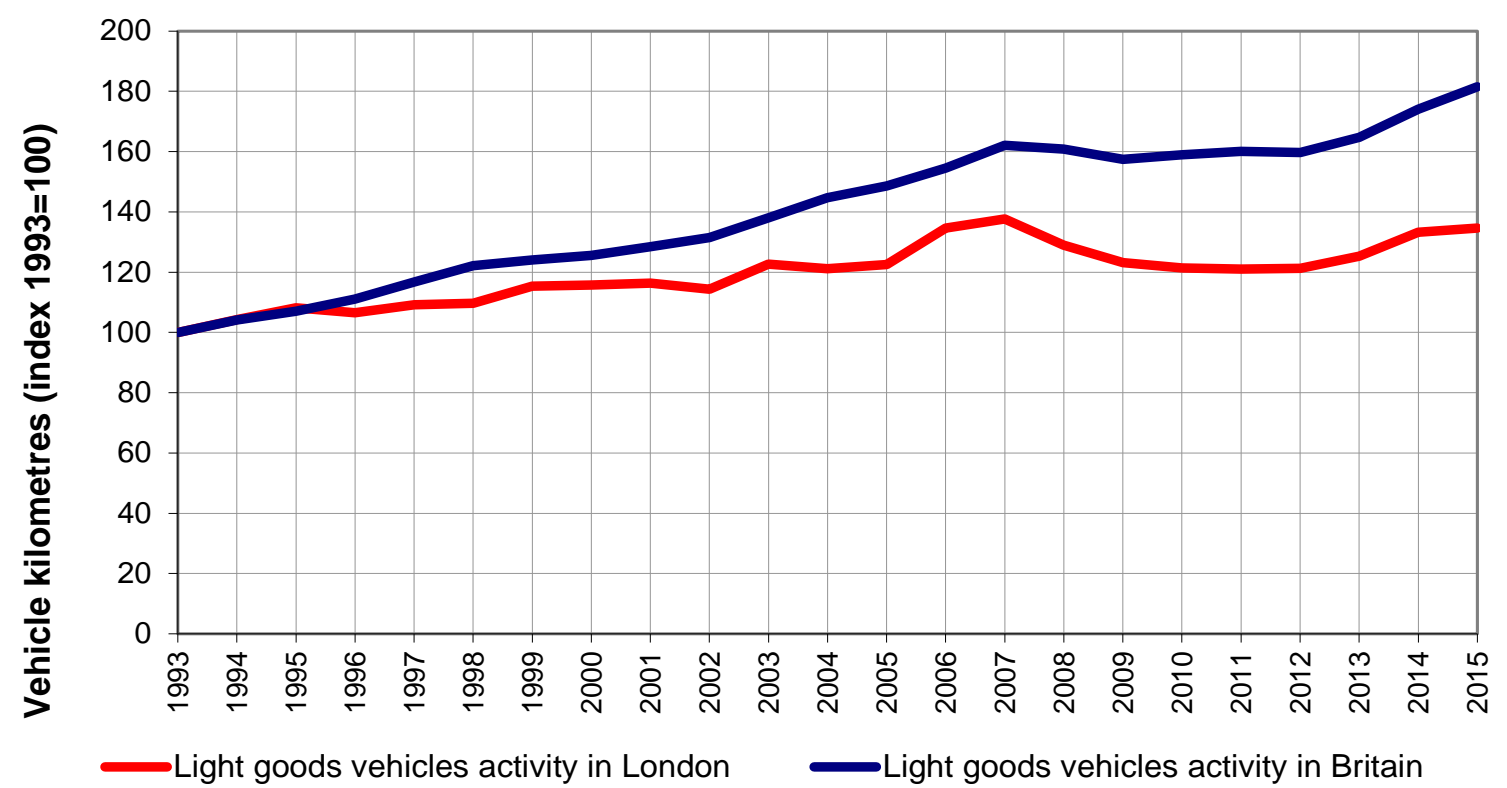

Note: Based on Department for Transport traffic data.

Source: Calculated from data in Transport for London, 2016; Department for Transport, 2016c.

Analysis of the vans sold in Britain between 1990 and 2007 suggests that the average gross weight and payload of LGVs has increased by 10\%-20\% over this period (McKinnon, et al., 2015). In addition, regulations governing vehicle production do not prevent manufacturers from increasing the length of LGVs with a growing proportion being produced with long wheelbases, often between 0.5 and 1.5 metres longer than their medium wheelbase equivalents. Assuming that the width and height of these vehicles are the same, the long wheelbase varieties have approximately $20 \%$ additional load space for every extra 0.5 metre of length compared with shorter LGVs, with little or no difference in gross weight (McKinnon, et al., 2015).

The reductions in total motorised traffic levels in London have been occurring at a time when London's population has been growing at an average rate of nine people per hour (1991 to 2011) and is expected to rise to 11 new Londoners per hour between 2011 and 2021 (Greater London Authority, 2016). Research by the Roads Task Force (2013a) suggested that London's population grew by $13 \%$ between 2000 and 2011, and that $13 \%$ more trips were made in London on an average day in 2011 compared to 2000. This increase in demand for passenger travel has been accommodated by growth in the use of public transport services, cycling and walking (Transport for London, 2016). Growing urban populations generate an increase in the demand for goods and services that have to be delivered and distributed in often very congested municipal areas. In London, not only has the absolute volume of urban freight grown (in terms of the flow of goods and services that require transportation), but also the speed of response required, with end users (both companies and consumers) requesting ever-shorter lead times between orders being placed for goods and services and their fulfilment. This is resulting in significant challenges for logistics operators in London and Britain more generally.

Road space reallocation has taken place in London over the last two decades as a result of the expansion of exclusive bus and cycle lanes as well as some pavement widening programmes, with dedicated bus lanes in the Congestion Charging Zone increasing from 24.5 miles in 2003 to 26.5 in 2007 (Barry, 2014). The deterioration in average traffic speeds, which have fallen by between $2 \%$ and $9 \%$ depending on location and time since 2008/9, (the current average being $13.6 \mathrm{~km}$ per hour, Transport for London, 2016), have also impacted on travel time reliability. Bus and cycle traffic priority schemes and junction redesign for safety purposes including the implementation of more advance stop lines have also contributed to reduced traffic speeds. The situation has been further exasperated by increasing road traffic delays which have risen over this same time period by between 17$31 \%$ (1.9 minutes per km travelled in the morning peak) in central London (Transport for London, 2016). These issues collectively contributed to a $30 \%$ decrease in the road network capacity in central London for private motorised vehicles between 1993 and 2009 (Transport for London, 2013). The task of last-mile delivery has also been additionally complicated by the fact that local depots from which to operate in inner and central London are 
becoming increasingly difficult to afford, due to increases in land values. This is leading to the suburbanisation and ex-urbanisation of these freight facilities, increasing the stem mileage journey for London operations (Broaddus et al., 2015).

Transport for London is expecting traffic congestion to further increase as a result of pressures on road space from new cycling and bus infrastructure and the growth in LGVs, with traffic congestion in central, inner and outer London predicted to rise by 60\%, 25\% and 15\% respectively by 2031 (Transport for London, 2015a).

\section{Online shopping and last-mile delivery in the UK}

Online retailers are striving to offer consumers ever-more responsive (and costly) last-mile delivery services in their efforts to increase sales and gain market share from their competitors, and as a result, often fail to cover the costs of these operations. As well as having serious consequences for online retailers and their financial viability, it also has important implications for LGV traffic levels associated with online orders, and their wider social and environmental impacts.

Survey work by the Office for National Statistics suggested that online shopping accounted for $14.2 \%$ of all retail spending in the UK in July 2016, equivalent to approximately $£ 50$ billion per year (Office for National Statistics, 2016). The growth in the proportion of total retail sales accounted for by online shopping has been rapid in recent years with an increase of 17.3\% in the average weekly spend recorded between July 2015 and July 2016 (Office for National Statistics, 2016). Analysis suggests that in the UK 'non-food small items' (i.e. parcels and packages) account for $62 \%$ of online retail sales, with grocery accounting for $17 \%$, 'takeaways and other home-delivered meals' $13 \%$ and 'non-food large items' (e.g. refrigerators, freezers and furniture), $8 \%$. In the last-mile delivery sector, 'non-food small items' (i.e. parcels and packages) account for the most significant element of last-mile delivery activity (900 million parcels per annum) followed by 'takeaways and other home-delivered meals' (270 million orders), 'grocery deliveries' (86 million orders), and 'non-food large items' (8.6 million items) (calculated from data in Barclays, 2014; Metapack, 2015; Office for National Statistics, 2016; Verdict, 2016; the reader is referred to Allen et al., 2017a for a more detailed discussion).

Forecasts suggest that online shopping sales will remain strong in Britain between 2016 and 2021, averaging between 10-12\% sales growth per annum (Mintel, 2016a). Factors likely to play an important role in the future growth of online shopping include:

i) Older people becoming more regular online shoppers,

ii) Young people who have grown up with the internet, using it for a major proportion of their retailing (55\% of those aged 16-34 have shopped online for groceries in the past year compared to $42 \%$ of those aged 45 64 and $32 \%$ of over-65s - Mintel, 2016b.),

iii) The closure of physical shops that are unable to compete,

iv) Increasing penetration rates of online shopping in the grocery sector (it accounted for approximately $4 \%$ of total food and drink sales in Britain in 2015 - calculated from data in Office for National Statistics, 2016),

v) The growing use of smart phones will make shopping, even when travelling, more convenient and easier (European Commission, 2012).

Despite the growth in consumer spending on online shopping in Britain, achieving profitability in this market is a far more challenging proposition for retailers and transport providers. Research has shown that the average operating profit margins for the UK's top-10 store-based (i.e. multi-channel) retailers have more than halved since 2011, from 6\% in 2011 to $2.5 \%$ in 2015 (OC\&C Strategy Consultants, 2016). A major factor in this is the mismatch between what consumers are willing to pay for the delivery and the cost of providing the delivery service. Research has suggested that the last-mile delivery of parcels is between 5 and 23 times more expensive than in-store purchases for retailers (depending on parcel size and delivery service), OC\&C Strategy Consultants (2016), with consumers being unwilling to meet these delivery costs (ibid). Despite this, and in their efforts to increase online sales, retailers are continuing to offer faster delivery services without covering or recouping these costs, and between 2013 and 2015, the proportion of next-day delivery for non-food online shopping increased by $50 \%$. Over the same time period, the proportion of consumers willing to wait 3-5 days for their parcel to arrive reduced by $10 \%$ (ibid).

Many retailers do not explicitly price their delivery services for online shopping orders, the costs being incorporated into the product purchase price. As a result, end consumers are not given adequate price signals, 
leading to the perception that delivery is in some way free which consequently fuels the demand for ever-faster and more responsive delivery arrangements which retailers provide in order to maintain market share. Changing this situation is likely to prove challenging as few consumers in Britain are prepared to pay more for home deliveries, with $83 \%$ routinely selecting the cheapest delivery option, and $81 \%$ stating that increased delivery or collection costs would put them off ordering online (Mintel, 2016a, 2016c). This under-pricing of last-mile delivery services has created financial difficulties for both pure-play and multi-channel retailers as well as their logistics providers (Allen et. al., 2016; Ruddick, 2015; Consultancy.uk, 2015). A major factor in the attempt to reduce the operating costs of these last-mile delivery operations involves attempting to increase the quantity of goods carried on each vehicle and the drop density associated with each vehicle's delivery operation (i.e. to minimise the inter-drop distance between delivery locations). Encouraging greater collaboration between online retailers and their transport operators so that each delivery vehicle could carry the products of multiple retailers for a given geographical delivery area could be a way forward (Allen et al., 2017b).

Table 2 summarises differences in markets served and delivery service arrangements between and within the various online shopping last-mile delivery sectors, focusing particularly on the transport impacts of these various last-mile delivery operations. Grocery deliveries, large non-food item deliveries, and restaurant and takeaway deliveries are each given a single column, given that there is relatively little variation in how these services are performed. However, given the far greater variation that exists in the last-mile delivery of small non-food items (i.e. parcels and packages), these deliveries have been given two separate columns to reflect the significant operational differences between express parcel carriers (i.e. next-day or longer delivery services) and same-day courier services in delivering to consumers. 
Table 2: Key service features of online shopping last-mile delivery systems by sector and provider

\begin{tabular}{|c|c|c|c|c|c|}
\hline \multirow{2}{*}{$\begin{array}{l}\text { Sector } \\
\text { Products delivered }\end{array}$} & \multirow{2}{*}{$\begin{array}{l}\text { Grocery retail } \\
\text { Food shopping }\end{array}$} & \multicolumn{2}{|c|}{ Non-food small items } & \multirow{2}{*}{\begin{tabular}{|c|}
$\begin{array}{c}\text { Non-food large } \\
\text { items }\end{array}$ \\
$\begin{array}{c}\text { Large white and } \\
\text { brown goods }\end{array}$ \\
\end{tabular}} & \multirow{2}{*}{$\begin{array}{c}\begin{array}{c}\text { Takeaways and } \\
\text { home-delivered } \\
\text { meals }\end{array} \\
\text { Ready to eat meals }\end{array}$} \\
\hline & & $\begin{array}{c}\text { Parcels and packages - by } \\
\text { parcel carrier }\end{array}$ & $\begin{array}{c}\text { Parcels and packages - by } \\
\text { courier }\end{array}$ & & \\
\hline $\begin{array}{l}\text { Typical lead time from order to } \\
\text { delivery (i.e. responsiveness of } \\
\text { delivery) }\end{array}$ & $\begin{array}{c}1 \text { or more days (but } 30-60 \\
\text { minutes in new rapid } \\
\text { response services) }\end{array}$ & 1 or more days & Same day & $\begin{array}{l}1 \text { day to several } \\
\text { weeks }\end{array}$ & $\begin{array}{l}\text { Usually within } 15-60 \\
\text { minutes }\end{array}$ \\
\hline $\begin{array}{l}\text { Incidence of first-time delivery } \\
\text { failure }\end{array}$ & Very low & High & Low-medium & Very low & Very low \\
\hline Return rates & Low & High & Low & Very low & Very low \\
\hline Type of delivery operation & Multi-drop rounds & Multi-drop rounds & $\begin{array}{l}\text { Single drop rounds (point to } \\
\text { point) }\end{array}$ & Multi-drop rounds & $\begin{array}{l}\text { Single drop rounds } \\
\text { (point to point) }\end{array}$ \\
\hline $\begin{array}{l}\text { Type of vehicle/s used for last- } \\
\text { mile delivery }\end{array}$ & $\begin{array}{l}\text { Vans (with some } \\
\text { motorbikes and bicycles) }\end{array}$ & $\begin{array}{l}\text { Vans (with some cars for } \\
\text { deliveries to residential } \\
\text { addresses) }\end{array}$ & $\begin{array}{l}\text { Motorbikes, bicycles, vans } \\
\text { and cars }\end{array}$ & Lorries & $\begin{array}{l}\text { Motorbikes, bicycles } \\
\text { and some cars }\end{array}$ \\
\hline $\begin{array}{l}\text { Typical number of orders } \\
\text { delivered per round trip }\end{array}$ & $10-15$ & $50-200$ & $1-5$ & $5-10$ & 1 \\
\hline Average size of delivery & Several bags full & $\begin{array}{c}\text { From one parcel (residential) } \\
\text { to multiple parcels } \\
\text { (businesses) }\end{array}$ & Usually one parcel or letter & $\begin{array}{l}\text { Single item but } \\
\text { large and heavy }\end{array}$ & Single bag/box \\
\hline $\begin{array}{l}\text { Bookable delivery times } \\
\text { available? }\end{array}$ & $\begin{array}{l}\text { Yes, 1- or 2-hour delivery } \\
\text { slots }\end{array}$ & \multicolumn{2}{|c|}{$\begin{array}{c}\text { Often not. But some carriers allow consumer selection of } \\
\text { delivery day or time (often for an additional charge). And some } \\
\text { carriers send message to consumer either one hour or the day } \\
\text { before delivery. }\end{array}$} & $\begin{array}{l}\text { Some offer 1- or 2- } \\
\text { hour delivery slots } \\
\text { for extra charge }\end{array}$ & $\begin{array}{l}\text { No, but usually within } \\
15-60 \text { mins of order }\end{array}$ \\
\hline Number of people on/in vehicle & One & One & One & Two & One \\
\hline $\begin{array}{l}\text { Locations from which delivery } \\
\text { vehicles are despatched }\end{array}$ & $\begin{array}{l}\text { Shops (supermarkets) and } \\
\text { fulfilment centres }\end{array}$ & Logistics depots & $\begin{array}{l}\text { Point-to-point: driver does not } \\
\text { return to depot between each } \\
\text { delivery and collection }\end{array}$ & Logistics depots & $\begin{array}{l}\text { Shops (restaurants } \\
\text { and takeaways) }\end{array}$ \\
\hline $\begin{array}{l}\text { Click \& Collect / collection point } \\
\text { service available? }\end{array}$ & Yes & Yes & Yes & Not normally & No \\
\hline $\begin{array}{l}\text { Who carries out the delivery } \\
\text { operations }\end{array}$ & Supermarket & Parcel carrier & Courier or parcel carrier & Logistics carrier & $\begin{array}{c}\text { Restaurant or } \\
\text { platform provider } \\
\text { with driver/cyclist }\end{array}$ \\
\hline $\begin{array}{l}\text { Change in delivery speed and } \\
\text { service over last two years }\end{array}$ & $\begin{array}{l}\text { Hours of delivery extended. } \\
\text { Click \& Collect service } \\
\text { improvement }\end{array}$ & $\begin{array}{l}\text { Faster delivery. } \\
\text { Click \& Collect service } \\
\text { improvement }\end{array}$ & No change & $\begin{array}{l}\text { More choice of } \\
\text { time slots }\end{array}$ & Faster delivery \\
\hline
\end{tabular}

Source: Based on the authors' own judgement derived from literature review and interviews as part of the FTC2050 project (www.ftc2050.com). 


\section{Current parcel delivery operations and last-mile challenges}

The growth in online shopping and the associated last-mile movement of these purchases is one of the factors in the observed increase in LGV activity in Britain and London. The vast majority of parcels and packages delivered to residential properties are not compatible with a standard sized letterbox with only $8 \%$ being deliverable (Verdict, 2016a; Table 3). In addition, some business-to-consumer (B2C) as well as the majority of business-to-business (B2B) parcels require a signature on delivery making it necessary for the consignee or a representative to be present to receive the delivery.

Table 3: Online sales of small items delivered in the UK in 2016

\begin{tabular}{|c|c|c|c|c|c|}
\hline \multirow[t]{2}{*}{ Product } & \multicolumn{4}{|c|}{ Online sales ( $£$ million and $\%$ ) } & \multirow{2}{*}{$\begin{array}{c}\text { Proportion } \\
\text { of total } \\
\text { online sales } \\
(\%)\end{array}$} \\
\hline & & 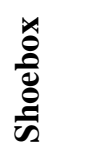 & 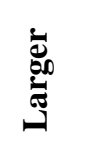 & 党 & \\
\hline Books & $42 \%$ & $33 \%$ & $25 \%$ & 1,152 & $3.1 \%$ \\
\hline Clothing \& footwear & $6 \%$ & $34 \%$ & $60 \%$ & 12,899 & $34.9 \%$ \\
\hline DIY \& gardening & $5 \%$ & $41 \%$ & $54 \%$ & 844 & $2.3 \%$ \\
\hline Electricals & $2 \%$ & $33 \%$ & $66 \%$ & 7,580 & $20.5 \%$ \\
\hline Furniture \& floorcoverings & $0 \%$ & $0 \%$ & $100 \%$ & 552 & $1.5 \%$ \\
\hline Health \& beauty & $18 \%$ & $51 \%$ & $31 \%$ & 1,386 & $3.7 \%$ \\
\hline Homewares & $2 \%$ & $32 \%$ & $66 \%$ & 1,656 & $4.5 \%$ \\
\hline Music \& film & $70 \%$ & $19 \%$ & $11 \%$ & 511 & $1.4 \%$ \\
\hline Proportion of total & $8 \%$ & $34 \%$ & $59 \%$ & $100 \%$ & $100.0 \%$ \\
\hline
\end{tabular}

Source: Calculated from data provided in Verdict, 2016a.

The substantial growth in total parcel volumes, largely due to the growth in online retailing (Allen et al., 2016) has led to profitability concerns for UK online retailers and their carriers (Consultancy.uk, 2015). There are several important operational factors Impacting on profitability:

i) Peak pressure: A carrier's ability to cope with the ever-growing additional demand for parcel deliveries during peak periods and the infrastructure investment required to maintain such a service. Retailers are adding to these peak demand pressures as they seek to boost sales and their competitive position by importing 'shopping frenzy' with concepts from the USA such as 'Black Friday' and 'Cyber Monday' (Herson, 2015). Retailers are also urging carriers to accept later cutoff times for next-day deliveries to gain customer share (ibid).

ii) Complex customer demands: Consumers are demanding ever faster, more reliable and convenient delivery services which have led carriers to offer timed delivery windows, parcel traceability and alternative delivery location options, including collection points and locker banks, all of which have cost and investment implications (Copenhagen Economics, 2013; Post and Parcel, 2015). Research has shown that $43 \%$ of consumers have had a negative experience with the delivery of online orders, and that $66 \%$ have chosen one retailer in preference to another because they provided a greater range of delivery options (Metapack, 2015). In addition, 45\% of consumers would be unlikely to shop again with an online retailer following a poor delivery experience. 
iii) Overcapacity in the sector: The Royal Mail (the formally nationalised post and parcel carrier in the UK) has estimated that there is approximately $20 \%$ annual spare capacity in the parcel market (Post and Parcel, 2015). New entrants to the last-mile market with new logistics business models such as Amazon and Uber may further exacerbate overcapacity if they expand their parcel handling facilities. This would increase the total parcel industry capacity in the short-term but whether this persisted in the longer-term would depend on whether all competitors would be able to survive in these circumstances. The expansion of parcels handling facilities by these new entrants may also exert further downward pressure on delivery prices (Bourke, 2015; Jinks, 2016; Lieb and Lieb, 2014; Oliver Wyman, 2015; Sumner-Rivers, 2015).

iv) Demand for $\mathrm{B} 2 \mathrm{C}$ and $\mathrm{C} 2 \mathrm{C}$ deliveries: $\mathrm{B} 2 \mathrm{C}$ and $\mathrm{C} 2 \mathrm{C}$ delivery has seen considerable growth but generates lower average revenues for parcel carriers compared to B2B deliveries. These markets also have attributes that make delivery less efficient, including; the sizeable first-time failure rates associated with deliveries to residential customers; and the proportions of single-parcel deliveries compared to multiple items per consignee in $\mathrm{B} 2 \mathrm{~B}$ operations. $\mathrm{B} 2 \mathrm{C}$ and $\mathrm{C} 2 \mathrm{C}$ deliveries also involve more suburban and ex-urban delivery locations, with lower drop densities and higher inter-drop distances compared to B2B.

v) The impacts of 'free' delivery: The decision by many retailers to provide 'free' delivery options in order to attract custom has resulted in low pricing models being demanded from carriers (Consultancy.uk, 2015). A 2016 survey of 350 online retailers found that $16 \%$ offered free delivery as standard, with 55\% offering it on orders exceeding a specified value threshold. Of interest was that $59 \%$ of these retailers charged less than $£ 5$ for delivery if the free delivery threshold was not met (Oracle, 2016). Ofcom found that $56 \%$ of adults rated free delivery as an important factor when choosing a retailer and that $55 \%$ had not completed an order because the cost of delivery was too high (Ofcom, 2015).

vi) The pressure of meeting delivery windows: Online retailers and parcel carriers offer a range of time guaranteed delivery services which range from any time within a specified number of days from the order being placed, through to specific times on a given day and even same-day services. Data suggests that $37 \%$ of orders despatched to consumers in July 2016 were sent 'economy' (i.e. with no assured delivery lead time, no specific delivery day or time-slot), $32 \%$ were despatched for next-day delivery, $4 \%$ using delivery services with greater definition than next-day (including same day, next day before 12:00, next day after 12:00, next day after 17:00, and Saturday or Sunday delivery), while $27 \%$ were despatched internationally, (IMRG and Metapack, 2016). Since 2013, there has been an increase in the proportion of parcels sent for next-day delivery and a related decline in parcels sent by economy service (IMRG and Metapack, 2016). The proportion of UK online retailers offering 6 or more delivery options to consumers increased from $3 \%$ in 2015 to $10 \%$ in 2016. Similarly, the proportion of retailers offering only one or two delivery options reduced from 55\% in 2015 to 35\% in 2016 (Oracle, 2016).

vii) Managing product returns: Unlike other supply chains, returned products from online shopping, represent a sizeable proportion of all goods delivered with $20 \%$ to $30 \%$ of all clothing and footwear purchased online (by value) being returned (Barclays, 2014; Verdict, 2016b). Estimates indicate that between $50 \%$ and $75 \%$ of these returns are paid for by online retailers rather than customers (Barclays, 2014; Oracle, 2016) reflecting the impact of price and service-level on customer retention and the focus on sales as opposed to profitability.

viii) Failed first-time deliveries: Failure rates are higher for deliveries to residential addresses compared to commercial addresses due to less than $10 \%$ of all parcels and packages ordered online (by value) being compatible with a standard letterbox (Verdict, 2016a). It has been estimated that $13-14 \%$ of all online shopping deliveries in the UK arrive either late or when the customer is not at home (IMRG, 2014a) costing retailers and carriers $£ 771$ million in 2014 (IMRG, 2014b). 
ix) Traffic conditions: Worsening road conditions and difficulties finding suitable kerbside parking space in urban centres is making parcel deliveries ever-more difficult to perform to exacting customer requirements. Average traffic speeds in London have declined between 2\% and 9\% over the last decade with average vehicle delays rising by between $17-31 \%$ in central London, impacting on journey time reliability (Transport for London, 2016). Parking difficulties are forcing drivers to park further from the point of delivery, cover increasing distances on foot and risk incurring parking penalties with the vehicle being used as a mini consolidation point.

x) Available logistics infrastructure: Affordable local depots from which to operate last-mile parcel deliveries are becoming increasingly difficult to find due to rising land values in London and other cities in Britain and elsewhere. These increases have forced many freight transport operators to relocate their central urban depots to cheaper peripheral areas (Hesse, 2008) which has led to the suburbanisation of warehousing and distribution facilities (Cidell, 2010; Hesse, 2008; Dablanc and Rakotonarivo, 2010). Often referred to as 'logistics sprawl' (Dablanc et al., 2014), this has the effect of increasing stem mileages (the distance from the depot to the first delivery address, and from the last delivery address back to the depot) resulting in increased vehicle kilometres. In the case of Paris, research has suggested that between 1974 and 2010, the typical stem mileage from parcel companies' depots to their delivery areas increased by 12 kilometres (from $6 \mathrm{~km}$ to $18 \mathrm{~km}$ ), Dablanc et al., (2016).

\section{Last-mile delivery practices in parcel operations}

The ways in which last-mile parcel operations are undertaken and their characteristics on-street are not well understood. From a local authority's perspective, the collective impacts of such activities where so many players can be involved can be hard to gauge due to the insular nature of each supply chain. As part of the EPSRC-funded Freight Traffic Control 2050 project (www.ftc2050.com), GPS tracking data from 83 parcel carrier vehicles and their drivers operating between the $25^{\text {th }}$ and $27^{\text {th }}$ October 2016 across the WC1, WC2 and W1 post sectors in London were obtained along with the daily manifest data for each vehicle in an attempt to better understand parcel operations. In addition to the GPS data, 25 vehicle rounds were accompanied by a surveyor who recorded round timings, parking places used, delivery/collection locations and any conflicts encountered. Figure 5 shows the routeing for one of the vehicle rounds studied, highlighting the extent of walking carried out by the driver as part of the last-mile transaction. 


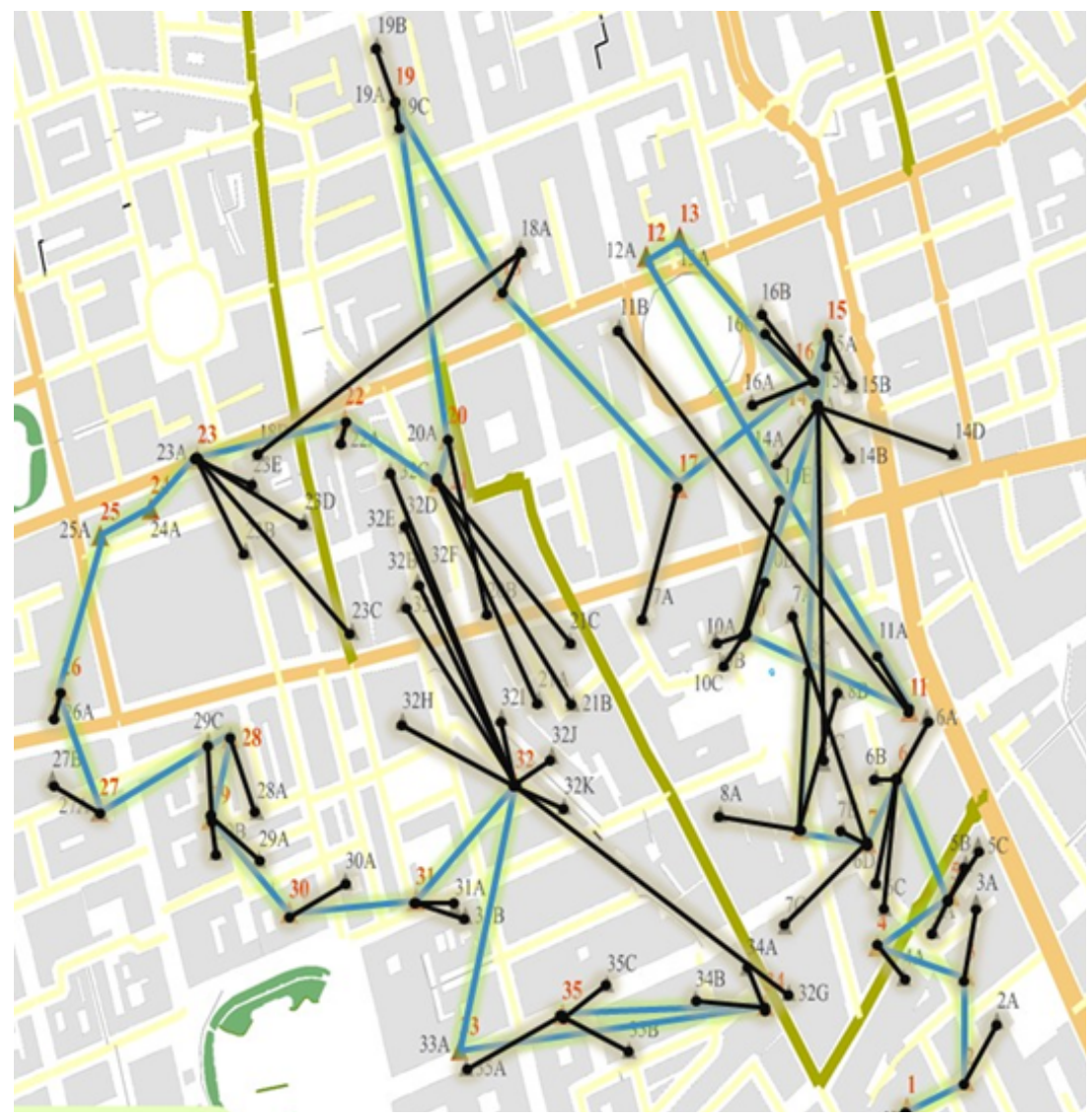

Figure notes: Red numbers represent the order in which deliveries were made to clients. Green lines represent the vehicle crow-flight service path. Black lines represent the walking paths to service clients from unloading points. The delivery area covers $1.6 \mathrm{~km}^{2}$, total driving time was $1.77 \mathrm{hrs}$; total parking time was 6.05 hrs; number of parking stops were 35; number of items delivered was 119; total round duration was 7.82 hrs, round distance was $6.7 \mathrm{~km}$ (excluding stem mileage to and from the depot at the start and end of the round).

From the data and surveyor observations, delivery/collection tasks were allocated to drivers each day based on pre-determined and largely fixed round structures, although some minor re-allocation of tasks were observed when a driver would otherwise have too much work to undertake. The order in which delivery and collection tasks were undertaken was left entirely to the driver's discretion, with time-dependent transactions taking priority in the way the round was structured. Depending on the driver's level of experience and familiarity with the area, this could lead to inefficiencies in service order and routing but interestingly, neither carrier used any form of routing and scheduling software to manage the last-mile transaction. Dialogue with operations and transport managers suggested that the inability to directly access a significant proportion of clients at their manifest address meant that optimisation software using this parameter as the delivery location inaccurately reflected where vehicles parked to make deliveries/collections, ignoring the walking element of rounds.

From the 25 accompanied rounds (Table 4), the average round duration, defined as the difference in time from leaving the depot and returning, excluding time spent in the depot, was 7.3 hours and the average distance driven within the delivery area (excluding stem mileage) was $11.9 \mathrm{~km}$ with a mean speed of $7 \mathrm{kph}$. Of interest from a policy perspective was the finding that for $62 \%$ of this time, the vehicle was parked while deliveries or collections were being made. This time included that spent unloading parcels, walking to customer's premises and gaining proof-of-delivery. The average distance walked was found to be $7.9 \mathrm{~km}$, equating to an average of $105 \mathrm{~m}$ per customer, with an average of 118 items delivered to 72 customers per round. The vehicles made 37 stops on average to 
service these customers, with $95 \%$ being on-street recording an average observed service time of 4.1 minutes per customer. Parking locations were not necessarily unique as drivers were observed returning to favoured parking locations two or more times during a round, particularly where timed deliveries or collections dictated. Relatively few items were collected on the rounds by the two carriers (9, on average). For one, collections were almost exclusively planned for the end of the round after all deliveries had been made, while for the other, collections were interspersed with deliveries. The former approach avoids issues associated with managing space in the van and the risk of mixing up deliveries and collections but is likely to be less efficient from a vehicle routing perspective.

Table 4: Vehicle round statistics for parcel deliveries $(n=25)$ studied in central London, October 2016

\begin{tabular}{|l|r|r|r|r|l|}
\hline Vehicle round statistic & Min & Max & Mean & St.Dev. & Unit \\
\hline $\begin{array}{l}\text { Round duration, of which: } \\
\text { - vehicle parked }\end{array}$ & $\begin{array}{r}5.1 \\
33 \%\end{array}$ & $\begin{array}{r}10.3 \\
77 \%\end{array}$ & $\begin{array}{r}7.3 \\
62 \%\end{array}$ & $\begin{array}{r}1.4 \\
11 \%\end{array}$ & $\begin{array}{l}\text { hour } \\
\%\end{array}$ \\
\hline Driving distance within delivery area & 3.6 & 20.5 & 11.9 & 5.1 & $\mathrm{~km}$ \\
\hline Average vehicle speed within delivery area & 2.6 & 12.3 & 7.0 & 2.4 & $\mathrm{kph}$ \\
\hline $\begin{array}{l}\text { No. of items delivered and } \\
\text { (collected) }\end{array}$ & $\begin{array}{r}57 \\
(1)\end{array}$ & $\begin{array}{r}274 \\
(62)\end{array}$ & $\begin{array}{r}118 \\
(9)\end{array}$ & $\begin{array}{r}46 \\
(12)\end{array}$ & $\#$ \\
\hline Total walking distance & 4.64 & 12.48 & 7.94 & 2.32 & $\mathrm{~km}$ \\
\hline Average walking distance per customer & 67 & 145 & 105 & 22.8 & $\begin{array}{l}\text { metres/ } \\
\text { customer }\end{array}$ \\
\hline No. of customers served & 32 & 120 & 72 & 23 & $\#$ \\
\hline $\begin{array}{l}\text { No. of parking stops, of which: } \\
\text { - proportion on street }\end{array}$ & 14 & 72 & 37 & $\begin{array}{r}12 \\
5 \%\end{array}$ & $\begin{array}{l}\# \\
\%\end{array}$ \\
\hline Time taken to deliver or collect (once parked) & 1.6 & 6.8 & 4.1 & 1.2 & $\begin{array}{l}\text { minutes/ } \\
\text { customer }\end{array}$ \\
\hline
\end{tabular}

London has seen a considerable shift to walking, cycling and the use of buses over the past 10 years which has resulted in increased dedicated cycle and bus lanes, reducing kerbside access for freight (Transport for London, 2016). As a result, last-mile parcel operations, characterised by large proportions of time spent walking with the vehicle parked by the roadside can come into direct conflict with an infrastructure system increasingly being designed and legislated in favour of passenger transportation (Allen and Browne, 2016). With the growth in last-mile delivery expected to grow (Mintel, 2016a), there is a need to fundamentally re-think how we cater for last-mile freight operations in urban centres which at present are actively discriminated against with UPS reporting parking fines of over $\$ 17 \mathrm{~m}$ from servicing clients in New York alone in 2016 (Jensen, 2017).

\section{Initiatives to improve the efficiency of $\mathrm{B} 2 \mathrm{C}$ and $\mathrm{B} 2 \mathrm{~B}$ parcel deliveries}

Online retailers have been taking several steps to better manage the costs of delivering parcels to customers (both in residential and commercial establishments - i.e. B2C and B2B). In addition to reducing costs, many of these initiatives result in greater efficiency in delivery operations, and consequently also lead to reductions in LGV traffic, and its associated social and environmental impacts. Online retailers are beginning to make greater use of delivery services that do not involve delivering to the residential address and thereby reducing the extent of failed deliveries. This practice reduces the time involved in driving and walking between residential delivery addresses and finding parking spaces. These alternative systems allow larger volumes of parcels to be delivered to a smaller number of locations without the risk of delivery failure, thereby reducing the unit cost of parcel delivery. Such services include: i) click and collect (for online retailers who also have a physical store presence), ii) collection points (including convenience stores and petrol stations) and iii) locker banks (which can be situated in locations such as railway stations, petrol stations, shopping centres, 
workplaces and residential estates). In each of these three delivery systems, the customer collects their goods from these alternative locations at a time that suits them.

i) Click \& Collect services are proving popular with store-based online retailers as they can help them avoid performing loss-making last-mile delivery operations and can also result in consumers undertaking more shopping in-store while collecting goods. Research suggests that across all types of purchases, $4 \%$ of individuals always make additional purchases when collecting their goods from a store, $11 \%$ often do, $60 \%$ sometimes do and $25 \%$ never do (Verdict, 2016b). Online sales that made use of Click \& Collect services in 2016 accounted for $25 \%$ of all online clothing and footwear sales in the UK (Verdict, 2016a). A survey of UK online retailers operating Click \& Collect in-store found that approximately $90 \%$ offered free deliveries to consumers using the service (Oracle, 2016). Some store-based online retailers with Click \& Collect facilities are opening them up to online-only retailers, generating a new revenue stream for store-based online retailers. Boots the Chemist has allowed its stores to be used for ASOS consumer collections, whilst Argos provides a similar service for eBay consumer collections (Retail Week in partnership with Metapack, 2016).

ii) Collection points are proving popular with convenience retailers as they provide an additional source of revenue. In terms of collection points, Royal Mail has a network of 11,500 Post Offices and delivery offices from which recipients can collect their parcels; Hermes, around 5,000 collection points located in independent shops and local convenience stores for parcel deliveries and collections; DPD, 2,500 shop-based collection points across the UK (Herson, 2015). Collection points and locker banks are currently far less widely used compared to Click \& Collect services due to the delivery charges levied, accounting for only $1 \%$ of total online sales in the UK in 2016 (Verdict, 2016a).

iii) Personal deliveries to the workplace are taken as a delivery option for some who would not otherwise be at home during the working day. While this helps to reduce delivery failure rates, it can have other negative consequences including the detrimental impact these deliveries place on companies' loading bays, internal building logistics and post-rooms. It can also add to the total number of vehicle visits made to the building, where in central London, personal parcel deliveries can represent between 40-60\% of parcel throughput in medium-larger sized multi-tenanted offices, (increasing to $90 \%$ of parcel throughput during the Christmas peak, Allen et al., 2017a). As a result of these issues, around $8 \%$ of offices are now banning staff from receiving personal deliveries at the workplace (Transport for London, 2015b) with the London Assembly calling for more companies in London to follow suit (London Assembly, 2017).

iv) Try-and-buy outlets aim to reduce the costs associated with managing returned products. A Czech online-only retailer, ZOOT, has implemented an approach in which clothing ordered by customers can be delivered to a 'Try \& Buy' store which the customer visits to try on items and decide if they are suitable. Half of all orders are delivered to the Try \& Buy facility within 24 hours of the order being placed and some deliveries take as little as three hours. Consumers only have to commit to buy the goods after trying them on (Mintel, 2016c).

v) Last-mile collaboration offers scope for UK parcel carriers to work together in making deliveries of online shopping orders in order to reduce infrastructure requirements and enhance the efficiency of their operations. Parcel carriers have traditionally viewed each other as competitors and have not countenanced such concepts, except when making deliveries to and collections from the most remote, rural locations that are difficult to serve such as the Scottish Highlands and Islands, and the Isle of Man (Allen et al., 2016). Such collaborations can also be adopted to address the difficulties posed by the cost of acquiring suitably-located depots in central urban areas. Gnewt Cargo, operating in central London is classed as a 'carrier's carrier', receiving parcels from carriers and suppliers in single HGV loads at its centrally-located depots and carrying out the lastmile transaction on their behalf using a fleet of electrically-powered LGVs (Allen and Browne, 2016). This reduces the number of LGVs having to deliver parcels in a given area, as well as 
reducing $\mathrm{CO}_{2}$ and air pollutant emissions. Urban consolidation centres (UCCs) located in several European cities provide similar collaborative solutions to deliveries in busy urban locations that can help to reduce total vehicle activity but question marks remain over the economic viability of some such schemes (Allen et al., 2012b). Research by Cherrett et al., (2017) suggested consolidating parcel carrier deliveries to university halls of residence in Southampton, UK, could reduce the current 13,000 annual observed courier visits to 300 for an annual service cost of approximately £18 per student.

vi) Logistics hotels are a concept where a municipality works with industrial partners to create multiuser logistics depots in central urban areas. The municipality of Paris is developing these as part of two key mixed-use developments in order to reduce freight vehicle journey distances in the urban area and also provide the opportunity to transfer goods to cleaner, alternatively-fuelled vehicles for final delivery. This approach is being implemented at Beaugrenelle (a $3000 \mathrm{~m}^{2}$ parking facility turned into a parcel cross dock facility), and at Chapelle International (a rail-connected site). In addition, the 2016 zoning ordinance of the city of Paris provides dedicated areas and land parcels for future logistics land uses (Allen and Browne, 2016).

vii) Shared drop zones are areas on-street, reserved for collection and delivery activity. In several French cities an approach called 'Espace de livraison de proximité' (ELP or in English, 'nearby delivery areas') was introduced and operated. Goods destined for customers in busy urban areas were instead delivered to an urban transhipment platform at which dedicated ELP staff load the goods onto trolleys, carts, bicycles and electric LGVs for the last-mile leg to shops and offices in the surrounding area. In Bordeaux, the ELP implementation was a collaboration between freight transport companies, the Chamber of Commerce of Bordeaux and the Bordeaux metropolitan authority which set up and co-finance the ELP system (Browne et al., 2012; Huschebeck, 2012; SUGAR, 2011). Similarly, in a district of Paris, the parcel carrier La Tournée established a 'virtual exchange point' system where its delivery staff received parcels which they sorted and then delivered locally on-foot using a trolley. The virtual exchange point could be a van or a garage and had no long-term storage facilities (Ducret, 2014). Other parcel carriers have experimented with 'mobile city hubs' that can include an LGV, a trailer or a barge. These mobile hubs are used as parcel storage facilities that can be easily moved around the urban area as required. Delivery staff collect their parcels from these mobile hubs and then make the deliveries using bicycles, LGVs or on on-foot, returning to the hub for to carry out further delivery rounds. Examples include the barges and associated bicycle deliveries that were operated by the parcel carrier Vert Chez Vous on the River Seine and the HGV trailer-based, so-called 'Mobile Depot' trialled by TNT in Brussels (Ducret, 2014). It should be noted that some of these schemes were only trials, and some were part of regular operations but have ceased to exist. For such schemes to endure in the longerterm it is necessary that they are based on a sound business model and that the costs and benefits of such schemes are equitably shared among the participating organisations.

viii) Delivery and Servicing Plans (DSPs) were introduced by Transport for London in 2008 in its London Freight Plan (Transport for London, 2008) and are intended to provide a framework to better manage all types of freight vehicle movement to and from individual commercial buildings. DSPs are the equivalent of a staff workplace travel plan for freight and can be made compulsory for new developments with more than a specified number of staff or over a certain size. By better managing freight flows and freight-related vehicle activity at sites, the safety, efficiency and reliability of deliveries to that location will be improved. DSPs are designed to help reduce freight vehicle activity, $\mathrm{CO}_{2}$ emissions, collisions and overall freight costs by reducing the total delivery and collection journeys required at sites (especially during peak periods) and ensuring use of safe and legal loading facilities. Ways in which these freight journeys can be reduced using a DSP approach involve changing procurement practices in terms of the way goods are ordered at the site, through better stock control, and by reducing the number of suppliers used (Transport for London, 2014). Changes to procurement practice to achieve this can involve those placing orders within an organisation or businesses sharing a given building or location to use the same suppliers (which is often referred to as joint procurement), and encouraging those placing orders to review how 
frequently the goods ordered need to be delivered (for instance having the goods delivered once per week rather than daily or several times per week). A pilot DSP project carried out at one of Transport for London's main offices in central London suggested that there could be a $20 \%$ reduction in the total number of delivery journeys to the site (Transport for London, 2009).

ix) 'Crowdshipping' is also becoming a viable means by which the vehicle activity required for parcel deliveries can be reduced. This involves 'enlisting people who are already travelling from points A to B to take a package along with them, making a stop along the way to drop it off' (US Postal Service, 2014). Members of the public, taxi drivers (or delivery drivers with spare capacity on their LGVs) who are already making journeys act as couriers for the distribution of parcels and other small items, thereby creating new informal logistics networks. Such crowdshipping services have emerged over the last five years and are provided via a range of crowdshipping online platforms. These services are most prominent in America with online platforms including Postmates, Zipments, Deliv, and Roadie (McKinnon, 2016). However, the emergence of crowdshipping services by Uber and Amazon threatens to change the nature of crowdshipping and result instead in the use of dedicated vehicle trips specifically for parcel delivery and which do not necessarily have a beneficial effect on traffic reduction (Allen et al., 2017a). Amazon has already commenced delivery operations using this approach in London and the rest of the Britain, while Uber has yet to launch its parcel delivery services (known as UberRUSH) in Britain.

\section{Conclusions}

LGVs are becoming an increasingly important component of road traffic in London and the UK both in relative and absolute terms. Reasons for their growth are not well understood due to having received relatively little research attention in comparison with car, $\mathrm{HGV}$ and public passenger transport. One major area for LGV growth has been in the delivery of small non-food items (i.e. packages and parcels) ordered online which account for the most important sector of online shopping in the UK both in terms of retail sales, and delivery activity. This has been heightened by the general increase in business-to-business and business-to-consumer e-commerce which is forecast to continue over the coming years.

The parcel distribution sector is extremely competitive, characterised by low profit margins and evermore user-focussed delivery services being offered to customers. The resulting effort required to meet these exacting delivery services often leads to poor vehicle utilisation in the last-mile operation to the consignee, as well as duplication of these delivery services in any given geographical location as competitors vie for business. Particular operational pressures on last-mile logistics providers created by e-commerce growth include: i) the peakiness of seasonal demand patterns; ii) reduced lead-times between customers placing orders and deliveries being made; iii) complex sets of delivery time services offered; iv) high delivery failure rates related to deliveries to residential addresses; v) the need to manage high levels of product return, and vi) the lack of affordable urban logistics depots and fulfilment centres from which to despatch these LGVs.

Added to these are physical changes to the urban infrastructure where the move towards cycling, walking and public transport have resulted in diminishing kerbside unloading space and access time along with a general loss in logistics land in urban centres. As a result, the number of LGV fleets required to meet the needs of last-mile parcel delivery in urban areas have been increasing leading to greater vehicle kilometres travelled. Given the high level of competition and lack of profitability among both online retailers and parcel carriers in the UK, there has been little innovation in last-mile delivery operations in terms of efforts to reduce the negative impacts of the last-mile.

A case study investigating current parcel delivery operations in central London identified the scale of the challenge facing the last-mile parcel delivery driver, highlighting the importance of walking which accounted for $62 \%$ of the total vehicle round time and $40 \%$ of the total round distance in the operations studied. With the average parcel delivery van making 37 stops per round, and $95 \%$ of these being at the kerbside, conflicts for space with other road users becomes inevitable, with many 
logistics companies incurring significant financial penalties for waiting infringements.

There are a range of initiatives that retailers and parcel carriers, sometimes in conjunction with city authorities, can implement to reduce the costs associated with last-mile delivery, without negatively impacting on customer service levels. Some of these initiatives are aimed at reducing the extent of deliveries to residential addresses, improving vehicle load factors and drop densities, reducing delivery failure rates and vehicle stopping requirements (e.g. click-and-collect services, collection points and locker banks). Other initiatives are aimed at i) improving the efficiency of unloading at the kerbside in busy urban areas; ii) reducing product return rates; iii) reducing personal deliveries to workplaces in congested locations; iv) providing suitable logistics facilities in urban locations from which last-mile deliveries can be operated to reduce stem mileage; v) encouraging businesses to work together in their product procurement in order to share suppliers and hence reduce delivery vehicles; vi) 'crowdshipping', where existing passenger and freight transport movements are used to make goods deliveries; and vii) fostering greater operational collaboration between parcel carriers in order to share work in given geographical locations, increasing vehicle loads, improving drop densities, and reducing the number of vehicles entering that location to make deliveries.

All of these initiatives have the potential to increase the efficiency of last-mile e-commerce deliveries. For retailers and parcel carriers it can lead to reductions in unit operating costs (and hence increased profitability). For customers (both businesses and personal shoppers) it reduces the number of deliveries required and hence the time spent (and lost) receiving them. It also reduces the necessary LGV traffic and reduces the pressure placed on the road network and kerbside infrastructure, and the associated social and environmental impacts of these delivery activities. Working against this however is the fact that market conditions continue to exacerbate the negative impacts of last-mile deliveries in urban areas, with fierce competition between retailers for market share and sales growth. This continues to result in ever-higher levels of delivery service being offered to customers, without the cost of these services being recovered through retailer delivery pricing policies. Despite the existence of initiatives to increase the efficiency of last-mile deliveries, urban traffic authorities are likely to face a major challenge in their efforts to manage the traffic and environmental impacts associated with last-mile delivery operations.

\section{Acknowledgments}

The authors gratefully acknowledge the EPSRC for funding this work through its financial support of Freight Traffic Control 2050 (www.ftc2050.com), EPSRC Grant Reference: EP/N02222X/1. Responsibility for the contents of the paper rests with the authors.

\section{References}

Allen, J., Browne, M. and Cherrett, T. (2012a) Survey Techniques in Urban Freight Transport Studies, Transport Reviews, 32 (3), pp.287-311.

Allen, J., Browne, M., Woodburn, A. and Leonardi, J. (2012b) The role of urban consolidation centres in sustainable freight transport, Transport Reviews, 32 (4), pp.473-90.

Allen, J. and Browne, M. (2016) Success factors of past initiatives and the role of public-private cooperation, Deliverable 2.3, CITYLAB project.

http://www.citylab-project.eu/deliverables/D2_3.pdf

Allen, J., Piecyk, M. and Piotrowska, M. (2016) An analysis of the parcels market and parcel carriers' operations in the UK, report produced as part of the Freight Traffic Control 2050 project, University of Westminster. 
Allen, J., Piecyk, M. and Piotrowska, M. (2017a) An analysis of online shopping and home delivery in the UK, report produced as part of the Freight Traffic Control 2050 project, University of Westminster.

Allen, J., Bektas, T., Cherrett, T., Friday, A., McLeod, F., Piecyk, M., Piotrowska, M. and Austwick, M.Z. (2017b) Enabling the Freight Traffic Controller for Collaborative Multi-drop Urban Logistics: Practical and Theoretical Challenges, paper 17-04295, presented at Transportation Research Board 96th Annual Meeting (TRB 2017), Washington D.C., 8-12 January, 17 pp.

Barclays (2014) The Last Mile: Exploring the online purchasing and delivery journey, Barclays. https://www.home.barclays/content/dam/barclayspublic/docs/BarclaysNews/2014/September/the-lastmile-report.pdf

Barry, J. (2014) Head of Bus Network Development, Transport for London, Personal interview, 7 April 72014.

Bourke, J (2015) Why Britain's parcel couriers are still struggling to deliver, The Independent, 10 April 2015.

http://www.independent.co.uk/news/business/analysis-and-features/why-britains-parcel-couriers-arestill-struggling-to-deliver-10166695.html

Broaddus, A., Browne, M. and Allen, J. (2015) Sustainable Freight: Impacts of the London Congestion Charge and Low Emissions Zone, Transportation Research Record, Volume 2478, Freight Systems, Vol. 2, pp. 1-11.

Browne, M., Rizet, C. and Allen, J. (2014) A comparative assessment of the light goods vehicle fleet and the scope to reduce its CO2 Emissions in the UK and France. Procedia - Social and Behavioral Sciences 125, pp. 334-344.

Browne, M., Allen, J., Nemoto, T., Patier, D. and Visser, J. (2012) Reducing Social and Environmental Impacts of Urban Freight Transport: A Review of Some Major Cities, The Seventh International Conference on City Logistics, Procedia - Social and Behavioral Sciences, 39, pp.19-33.

Cherrett, T; Dickinson, J; McLeod, F; Sit, J; Bailey, G; Whittle, G (2017) Logistics impacts of students online shopping - Evaluating delivery consolidation to halls of residence. Transportation Research Part C, 78, pp111-128. http://dx.doi.org/10.1016/j.trc.2017.02.021

Cidell, J. (2010) Concentration and decentralization: the new geography of freight distribution in US metropolitan areas. Journal of Transport Geography 18, 363-371.

Commission for Integrated Transport (2010) Vans and the Economy, CfIT.

Copenhagen Economics (2013) E-commerce and delivery: A study of the state of play of EU parcel markets with particular emphasis on e-commerce, European Commission.

http://ec.europa.eu/internal_market/post/doc/studies/20130715_ce_e-commerce-and-delivery-finalreport_en.pdf

Consultancy.uk (2015) Parcel delivery sector in a squeeze, say consultants, 6 January.

http://www.consultancy.uk/news/1291/parcel-delivery-sector-in-a-squeeze-say-consultants

Dablanc, L. and Rakotonarivo, D. (2010) The impacts of logistics sprawl: How does the location of parcel transport terminals affect the energy efficiency of goods' movements in Paris and what can we do about it?, The Sixth International Conference on City Logistics. Procedia Social and Behavioral Sciences 2 (3), 6087-6096. 
Dablanc, L., Ogilvie, S. and Goodchild, A. (2014) Logistics Sprawl: Differential Warehousing Development Patterns in Los Angeles, California, and Seattle, Washington. Transportation Research Record: Journal of the Transportation Research Board, 2410, pp.105-112.

Dablanc, L., Blanquart, C., Combes, F., Heitz, A., Klausberg, J., Koning, M., Liu, Z., de Oliveira, L. and Seidel, S. (2016) CITYLAB Observatory of Strategic Developments Impacting Urban Logistics, Deliverable 2.1, CITYLAB project.

Department for Transport (2004) Survey of Privately Owned Vans: Results of survey, October 2002 September 2003, SB (04) 21, Department for Transport.

Department for Transport (2007) Road Freight Statistics 2006, section on The activity of GBregistered vans in Great Britain: 2003 - 2005, Department for Transport.

Department for Transport (2009) Van Activity Baseline Survey 2008: Provisional Results, London: Department for Transport.

Department for Transport (2016a) Road Traffic Statistics 2016 edition, Department for Transport.

Department for Transport (2016b) Vehicle Licensing Statistics, Department for Transport.

Department for Transport (2016c) Transport Statistics Great Britain 2016 edition, Department for Transport.

Ducret, R. (2014) Parcel deliveries and urban logistics: changes and challenges in the courier express and parcel sector in Europe-the French case, Research in Transportation Business \& Management, 11, pp.15-22.

European Commission (2012) An integrated parcel delivery market for the growth of e-commerce in the EU, Green Paper, COM(2012) 698 final, European Commission.

Greater London Authority (GLA) (2016) The London Plan, GLA Intelligence.

Herson, M. (2015) Metamorphosis of UK Parcels Market, 22 June, Post and Parcel. http://postandparcel.info/65831/in-depth/metamorphosis-of-uk-parcels-market/

Hesse, M. (2008) The City as a Terminal: The Urban Context of Logistics and Freight Transport. Aldershot: Ashgate.

Huschebeck, M. (2012) Espace de Livraison de Proximité, Bordeaux, ELTIS case study. http://www.eltis.org/index.php?id=13\&lang $1=e n \& s t u d y \_i d=1284$

IMRG and Metapack (2016) IMRG MetaPack UK Delivery Index Report, Metapack. https://www.imrg.org/data-and-reports/imrg-metapack-delivery-indexes/

IMRG (2014a) UK Consumer Home Delivery Review 2014, IMRG.

IMRG (2014b) Valuing Home Delivery Review 2014, IMRG.

Jensen, T.F. (2017) Viewpoint from UPS. Presentation 17-21812, presented at Transportation Research Board 96th Annual Meeting (TRB 2017), Washington D.C., 8-12 January.

Jinks, D. (2016) The Uberfication of Deliveries: Why Uber's move into logistics will transform the delivery market and encourage 'The Sharing Economy Revolution', Parcelhero Industry Report.

https://www.parcelhero.com/content/downloads/pdfs/uber/uberreport.pdf 
Lieb, R. and Lieb, K. (2014) Is Amazon a 3PL?, Supply Chain Quarterly, Quarter 3,

http://www.supplychainquarterly.com/topics/Logistics/20141027-is-amazon-a-3pl/

London Assembly (2017) London Stalling: Reducing Traffic Congestion in London, London Assembly.

https://www.london.gov.uk/about-us/london-assembly/london-assembly-publications/london-stallingreducing-traffic-congestion

McKinnon, A. (2016) Crowdshipping: A communal approach to reducing urban traffic levels?, Logistics White Paper 1/2016, Alan McKinnon.

http://www.alanmckinnon.co.uk/story_layout.html?IDX=714\&b=56

McKinnon, A., Allen, J. and Woodburn, A. (2015) Development of Greener Vehicles, Aircraft and Ships, chapter in McKinnon, A., Browne, M., Whiteing, A. and Piecyk, M. (eds.) Green Logistics: Improving the Environmental Sustainability of Logistics, Third Edition, Kogan Page, London, pp.165-193.

Metapack (2015) Christmas delivery volumes: the 'tsunami effect', press release, 22 January, Metapack.

http://www.metapack.com/press-release/christmas-delivery-volumes-the-tsunami-effect/

Micros (2014) Multi-channel Retail Delivery Report 2014, Micros.

http://www.essentialretail.com/uploads/pages_420_52e111437390f.pdf

Mintel (2016a) Online Retailing - UK, July 2016, Mintel.

Mintel (2016b) Online Grocery Retailing - UK, March 2016, Mintel.

Mintel (2016c) How ZOOT is tackling online returns in apparel retailing, 31 August, Mintel.

OC\&C Strategy Consultants (2016) Reinventing the Last Mile, Report, OC\&C Strategy Consultants. http://www.occstrategy.co.uk/news-and-media/2016/03/reinventing-the-last-mile

Ofcom (2015) Annual Monitoring Update on the Postal Market: Financial Year 2014-15, Ofcom. https://www.ofcom.org.uk/_data/assets/pdf_file/0025/56923/annual_monitoring_update_201415.pdf

Office for National Statistics (ONS) (2016) Retail sales index - internet sales, ONS.

https://www.ons.gov.uk/businessindustryandtrade/retailindustry/datasets/retailsalesindexinternetsales

Oliver Wyman (2015) Amazon's Move into Delivery Logistics, Oliver Wyman.

http://www.oliverwyman.com/content/dam/oliver-

wyman/europe/germany/de/insights/publications/2015/mar/Amazon\%E2\%80\%99s\%20Move\%20Into \%20Delivery\%20Logistics_email.pdf

Oracle (2016) Delivering Retail 2016 - Executive Report, Oracle.

https://go.oracle.com/LP=39022/?

Post and Parcel (2015) Royal Mail parcels growth offsets decline in mail revenues, 19 November, Post and Parcel.

http://postandparcel.info/69477/news/royal-mail-sees-parcels-growth-offset-decline-in-mail-revenues/

Retail Week in partnership with Metapack (2016) Bridging the Delivery Gap, Retail Week Connect Reports, Retail Week. 
https://www.metapack.com/wp-content/uploads/2016/05/Bridging_the_Delivery_Gap_Report.pdf

Roads Task Force (2013a) Roads Task Force - Technical Note 1: What is the over-arching transport and travel context to which the Roads Task Force needs to have regard?, TfL. Available at: http://www.tfl.gov.uk/assets/downloads/corporate/technical-note-01-what-is-the-over-archingtransport-and-travel-context.pdf

Roads Task Force (2013b) Roads Task Force - Technical Note 10 - What is the capacity of the road network for private motorised traffic and how has this changed over time?, Transport for London.

Ruddick, G. (2015) Why are Amazon and online retailers struggling to make money?, The Daily Telegraph, 7 Jan 2015.

http://www.telegraph.co.uk/finance/newsbysector/retailandconsumer/11330696/Why-are-Amazonand-online-retailers-struggling-to-make-money.html

SUGAR (2011) City Logistics Best Practices: A Handbook for City Authorities, SUGAR. http://www.eltis.org/index.php?ID1=6\&id=62\&list=\&concept_id=3

Sumner-Rivers, R. (2015) Amazon's Prime Ambition, Parcelhero Industry Report. https://www.parcelhero.com/content/downloads/pdfs/amazon/amazons-prime-ambition-parcelheroindustry-report.pdf

Transport for London (2008) London Freight Plan - Sustainable freight distribution: a plan for London, Transport for London. Available at:

Transport for London (2009) A Pilot Delivery Servicing Plan for TfL's Palestra Offices in Southwark : A Case Study, Transport for London.

Transport for London (2013) Travel in London Report 6, Transport for London.

Transport for London. (2014) Delivery and Servicing Plans: Making freight work for you, Transport for London.

Transport for London (2015a) Freight Forum, 20 March, London.

Transport for London (2015b) Office Freight: Understanding deliveries to offices, November 2015, internal market research, Transport for London.

Transport for London (2016) Travel in London: Report 9, Transport for London.

US Postal Service (2014) Using the 'Crowd' to Deliver Packages, Issue in Focus. Office of the Inspector General, Washington DC.

https://www.uspsoig.gov/sites/default/files/document-library-

files/2015/using_the_crowd_to_deliver_packages_0.pdf

Verdict (2016a) E-retail in the UK, Verdict.

Verdict (2016b) Click \& Collect in the UK, Verdict. 